\title{
PELATIHAN "BISNIS KELUARGA" BAGI KAUM WANITA DALAM MENDUKUNG TERCIPTANYA KEMANDIRIAN EKONOMI DAERAH DI SOLORAYA
}

\author{
Shandy Marsono ${ }^{1)}$ \\ Irwan Christanto Edy ${ }^{2)}$ \\ Heriyanta Budi Utama ${ }^{3)}$ \\ STIE Adi Unggul Bhirawa Surakarta \\ irwan_aub@yahoo.co.id
}

\begin{abstract}
ABSTRAK
Pemberdayaan kaum wanita binaan Dinas Sosial di Panti Pelayanan Sosial Wanita "Wanodyatama" Surakarta, merupakan kegiatan yang sangat penting dalam meningkatkan kualitas Sumber Daya Manusia Indonesia. Permasalahan yang dihadapi kaum wanita meliputi bidang sosial dan ekonomi. Oleh karena itu pemberdayaan kaum wanita binaan Dinas Sosial diharapkan mampu memberikan peningkatan kualitas individu baik dari kualitas karakter maupun ketrampilan bidang ekonomi. Berdasarkan kajian situasi Tim pengabdian pada masyarakat menyelenggarakan kegiatan penyuluhan dan pelatihan pemberdayaan kaum wanita binaan di Panti Pelayanan Sosial Wanita "Wanodyatama" Surakarta. Dalam kegiatan ini memberikan dampak pada kaum wanita binaan Panti Palayanan Sosial Dinas Sosial "Wanodyatama" Surakarta sehingga mereka 1)memiliki pemahaman dan motivasi untuk kewirausahaan, 2)memiliki ketrampilan tentang bisnis keluarga (family business). Komunikasi yang umpan balik mampu meningkatkan partisipasi dan motivasi peserta kegiatan dalam memahami setiap materi yang diberikan. Pengetahuan, pemahaman dan motivasi tentang Bisnis Keluarga ini menjadi modal awal bagi kaum wanita dapat mengembangkan bisnis yang berbasis pada keluarga.
\end{abstract}

Kata kunci : Bisnis Keluarga, Pemberdayaan Wanita, Kewirausahaan

\section{PENDAHULUAN}

Pemberdayaan berasal dari kata "daya" yang mendapat awalan ber menjadi kata "berdaya", artinya memiliki atau mempunyai daya. Daya artinya kekuatan, berdaya artinya memiliki kekuatan. Kata berdaya apabila diberi awalan pe- dan sisipan - m- serta akhiran -an menajdi "pemberdayaan" artinya membuat sesuatu menjadi berdaya atau mem[unyai daya atau mempunyai kekuatan. Pemberdayaan dalam bahasa Indonesia merupakan terjemahan dari "empowerment" dalam bahasa Inggris, menurut Merriam Webster dalam Oxford English Dictionary mengandung dua pengertian, yaitu (a) to give ability or enable to, yang diterjemahkan sebagai memberi kecakapan atau kemampuan atau memungkinkan untuk; (b) to give power or uthority to yang berarti memberi kekuasaan.

Berdasarkan penelitian kepustakaan tentang pengertian "pemberdayaan" dinyatakan bahwa proses pemberdayaan mengandung dua kecenderungan. Pertama, yang menekankan kepada proses memberikan atau mengalihkan sebagai kekuasaaan, kekuatan atau kemampuan kepada masyarakat agar individu menjadi lebih berdaya, yang merupakan makna kecenderungan primer. Sedangkan kecenderungan kedua yaitu menekankan pada proses menstimulasi, mendorong atau memotivasi individu agar mempunyai kemampuan atau keberadayaan untuk menentukan apa yang menjadi pilihan hidupnya melalui proses dialog, yang merupakan makna kecenderungan sekunder. (Onny S. Priyono dan Pranaka, 1996 : 56-57 dalam Roesmidi, H., dan Riza Risyanti, 
2006 : 2). Dengan demikian terlihat bahwa pemberdayaan bukanlah proses sepihak melainkan proses dua pihak yang dijalankan untuk kepentingan bersama.

Undang-Undang Dasar 1945 yang dijabarkan dalam peraturan perundang-undangan yang lebih rendah pada asasnya mengandung prinsip persamaan hak dan kewajiban bagi laki-laki maupun wanita tanpa ada perbedaan dalam segala bidang. Pasal 26 ayat (1) UUD 1945 menyatakan bahwa semua warga negara bersamaan kedudukannya di dalam hukum. Pasal 27 ayat (2) UUD 1945 bahwa tiap-tiap warga negara berhak atas pekerjaan yang layak bagi kemanusiaan. Selain itu tertuang dalam Undang-Undang No. 7 tahun 1984 tentang Pergeseran Konvensi Penghapusan Segala Bentuk Diskriminasi terhadap Wanita, dinyatakan bahwa tujuan untuk mencapai kedudukan setara (equal status) wanita sebagai peserta, pengambil keputusan, dan penikmat di dalam kehidupan politik, ekonomi, sosial, dan budaya. Dan dinyatakan untuk memberdayakan (empower) wanita dan laki-laki perlu kerjasama sebagai mitra sejajar dan memberi inspirasi kepada generasi baru kaum wanita dan laki-laki untuk bekerja sama demi kesetaraan, pembangunan berkelanjutan dan perdamaian (Priyono, 198-229 dalam Roesmidi H., dan Riza Risyanti. 2006). Pendekatan kebijakan yang berkaitan dengan kedudukan wanita dalam pembangunan (women in development / WID) disebutkan oleh Moser, terdapat lima cara, yaitu :

1. Pendekatan kesejahteraaan (the welfare approach)

2. Pendekatan keadilan (the equity approach)

3. Pendekatan tentang pengentasan kemiskinan (the anti porerty approach)

4. Pendekatan efisiensi (the efficiency approach)

5. Pendekatan pemberdayaan (the empowerment approach)

Pendekatan kelima, yaitu pendekatan pemberdayaan menekankan pada fakta bahwa wanita mengalami penekanan yang berbeda menurut bangsa, kelas sosial sejarah penjajahan kolonial, dan kedudukannya dalam ekonomi internasional pada masa kini. Dengan demikian wanita tetap harus pada tingkatan yang berbeda. Pendekatan ini juga menekankan pentingnya bagi wanita untuk meningkatkan keberadaannya dan mengartikan pemberdayaan bukan konteks mendominasi orang lain dengan makna apa yang diperoleh wanita akan merupakan kehilangan bagi lelaki, melainkan menempatkan pemberdayaan dalam arti kecakapan atau kemampuan wanita untuk meningkatkan kemandirian (self reliance) dan kekuatan dalam dirinya.

Pemberdayaan wanita harus dimulai dari diri wanita itu sendiri, dimana pendidikan merupakan faktor kunci sebagai model utama dari pemberdayaan wanita tersebut, yang ditunjang dan dilengkapi model pemberdayaan di bidang psikologi, sosial budaya, ekonomi, dan politik. Pada umumnya, profil wanita (dewasa) di pedesaan adalah miskin, dibebani berbagai jenis pekerjaan, buta aksara, bertanggung jawab atas kesehatan dan kesejahteraan anggota keluarganya. Menurut World Education Report, 1993 kurang lebih 905 juta laki-laki dan wanita yang merupakan hampir seperempat dari penduduk dewasa dunia adalah buta aksara. Dari jumlah ini, 587 juta atau 65 persen adalah wanita (United Nations, 1995: 71 dalam Onny S. Priyono, 208). Berdasarkan kajian situasi tersebut maka tim pelaksana pengabdian pada masyarakat menyelenggarakan kegiatan penyuluhan dan pelatihan tentang pemberdayaan wanita dengan kegiatan membangun bisnis keluarga di Panti Pelayanan Sosial Wanita "Wanodyatama" Surakarta.

\section{KAJIAN TEORI}

Family business (bisnis keluarga) merupakan salah satu bentuk bisnis yang melibatkan sebagian anggota keluarga di dalam kepemilikan atau operasi bisnis. Batasan lain tentang 
perusahaan diberikan oleh John L. Ward dan Craig E. Arnoff. Menurutnya, suatu perusahaan dinamakan perusahaan keluarga apabila terdiri dari dua atau lebih anggota keluarga yang mengawasi keuangan perusahaan. Sedangkan menurut Robert G. Donnelley dalam bukunya "The Fanily Business" suatu organisasi dinamakan perusahaan keluarga apabila paling sedikit ada keterlibatan dua generasi dalam keluarga itu dan mereka mempengaruhi kebijakan perusahaan.

Jadi dapat disimpulkan bisnis keluarga merupakan salah satu bentuk bisnis yang melibatkan sebagian anggota keluarga di dalam kepemilikan atau operasi bisnis. Efektif atau tidaknya peran keluarga dalam perusahaan dapat dilihat dari ketiga bentuk bisnis keluarga berikut. Karakter dari ketiga bentuk ini tidak sama yaitu :

1. Family owned business (FOB). Pada bentuk FOB keluarga hanya sebagai shareholder, pengelolaan perusahaan diserahkan kepada eksekutif profesional dari luar lingkungan keluarga, dan saudara yang lain tidak ikut mengendalikan perusahaan.

2. Family business $(F B)$. Pada FB, keluarga bertindak sebagai shareholder juga mengurus perusahaan artinya perusahaan dimiliki dan dikelola oleh anggota keluarga pendiri.

3. Business family $(B F)$. Bentuk perusahaan $\mathrm{BF}$ keluarga sebagai pemilik perusahaan cenderung menekankan pada hubungan kekerabatan saja.

Dalam membangun bisnis bersama keluarga atau pasangan terlebih dahulu harus jelas mendefinisikan bentuk usaha keluarga tersebut, yaitu family business atau business family.

Kedua bentuk bisnis itu berbeda, FB lebih menekankan pada profesionalitas dari keluarga yang mengoperasikan atau profesional yang bekerja di perusahaan itu. Sedangkan BF, menekankan pada hubungan kekeluargaan. Walaupun bisnis dikelola bersama keluarga, perusahaan tetap harus menerapkan prinsip good corporate governance (tata kelola perusahaan yang baik).

Seiring dengan tumbuh dan berkembangnya perusahaan, tidak jarang perusahaan keluarga "berubah bentuk" dari FB menjadi FOB, misalnya: Salim Group, Lippo, Bakrie Group, Ciputra, dan lain-lain. Apapun bentuk atau golongan bisnis keluarga yang dipilih, keluarga harus mampu mengatasi sejumlah masalah yang sering timbul, antara lain soal kepemimpinan, konflik, suksesi, transparansi, kompetisi dan budaya perusahaan.Motivasi orang untuk membuka bisnis bersama keluarga bermacam-macam, ada yang menginginkan bisnis keluarga sebagai sumber penghasilan utama, sementara yang lain hanya untuk sampingan, penyaluran minat dan hobi saja, atau meneruskan usaha keluarga.

Masalah-masalah yang berhubungan dengan bisnis keluarga dapat dengan mudah membutakan orang muda untuk mengambil keuntungan di dalam bisnis. Banyak keuntungan yang berhubungan dengan keterlibatan keluarga seharusnya diakui dan digunakan untuk merekrut anggota keluarga agar bekerja dalam perusahaan keluarga. Keuntungan datang dari hubungan kekluargaan yang kuat, anggota -anggota keluarga tertarik pada bisnis karena ikatan keluar.Memulai dari usaha kecil bersama keluarga - dengan suami, anak, atau sanak saudara bisa menjadi tantangan yang unik.

Di sisi lain, ini juga sangat membantu untuk urusan kepercayaan dan cara yang bagus untuk mengajak semua anggota keluarga untuk bersama-sama demi keamanan generasi selanjutnya.Keuntungan utama dari menjalankan bisnis dengan keluarga adalah adanya kepercayaan yang tidak didapatkan dari bisnis yang tidak berorientasi pada keluarga. Karena adanya kepercayaan dan hubungan keluarga inilah, anggota keluarga bisa bekerja lebih giat dan tidak membutuhkan kontrak legal dan permasalahan lain yang berkaitan dengan karyawan. Keuntungan lain adalah, terlepas dari banyaknya argumen, keluarga memiliki kecenderungan 
untuk tetap bersatu dalam masa-masa sulit. Hal ini disebabkan karena setiap anggota memiliki pemahaman yang lebih terhadap anggota keluarga yang lain, dan memiliki argumen, kerja sama, dan pengalaman negatif bersama-sama. Terlepas dari semua keuntungan memiliki bisnis keluarga, ada beberapa hal yang harus diperhatikan:

1. Mencampuradukkan bisnis dengan urusan pribadi dan keluarga bisa berdampak buruk pada hubungan keluarga. Pastikan anda membuat batasan-batasan yang jelas tentang dimana dan kapan anda bisa berbicara tentang bisnis.

2. Pastikan bahwa komunikasi tidak menjadi halangan. Adakanlah pertemuan rutin untuk membahas perkembangan dan perbedaan pendapat.

3. Perlakukan bisnis keluarga sebagaimana mestinya. Masalah yang sering terjadi dalam bisnis keluarga adalah terlalu berfokus pada 'keluarga' daripada bisnis.

4. Pastikan bahwa setiap orang memiliki peran yang jelas. Ini akan membantu untuk menumbuhkan lingkungan bisnis.

5. Anggota keluarga yang berada di dalam bisnis harus diperlakukan secara adil. Tidak boleh ada pilih kasih dalam bisnis. Gaji dan keuntungan yang adil dapat menjadi poin awal yang bagus.

6. Berusahalah mengembangkan rencana pergantian. Siapa yang akan mengambil alih bisnis setelah anda pensiun? Contohnya, apakah anak saudara anda atau anak anda? Ini dengan asusmsi bahwa saudara anda dan anda memiliki saham kepemilikan atas perusahaan.

7. Jika anak anda akan bergabung dalam bisnis, usahakan agar mereka mendapat pengalaman di luar bisnis keluarga selama 3-5 tahun sebelum mereka bergabung. Hal ini akan memberi mereka perspektif atau pandangan yang berharga tentang bagaimana bisnis seharusnya dijalankan di luar setting keluarga

Dari masalah-masalah yang sering muncul dalam bisnis keluarga, terutama masalah profesionalisme, akhirnya muncul mitos, "generasi pertama membangun, generasi kedua menikmati, dan generasi ketiga menghancurkan". Dan, masalah kepemimpinan dalam perusahaan keluarga, masalah konflik yang sering terjadi dalam bisnis keluarga, suksesi, kompetensi, dan budaya dalam perusahaan keluarga sebagai tawaran paradigma baru dalam bisnis keluarga. Semua ini tidak lain sebagai counter attack terhadap mitos: "generasi pertama membangun, generasi kedua menikmati, dan generasi ketiga menghancurkan”.

\section{MATERI DAN METODE}

Dengan permasalahan yang ada, maka tim pelaksana Pengabdian pada Masyarakat STIEAUB Surakarta menawarkan penyelesaian dalam bentuk memberikan pelatihan ketrampilan tentang bisnis keluarga. Adapun materi penyuluhan yang akan diberikan kepada kaum wanita binaan Panti Pelayanan Sosial Wanita "Wanodyatama" Dinas Sosial Kota Surakarta adalah :

1. Penyuluhan tentang membangun bisnis keluarga

2. Penyuluhan tentang kewirausahaan

3. Praktek bisnis keluarga usaha kuliner

Dalam kegiatan pengabdian pada masyarakat ini, bentuk kegiatan yang digunakan mengacu pada kerangka pemecahan masalah sebagai berikut : 


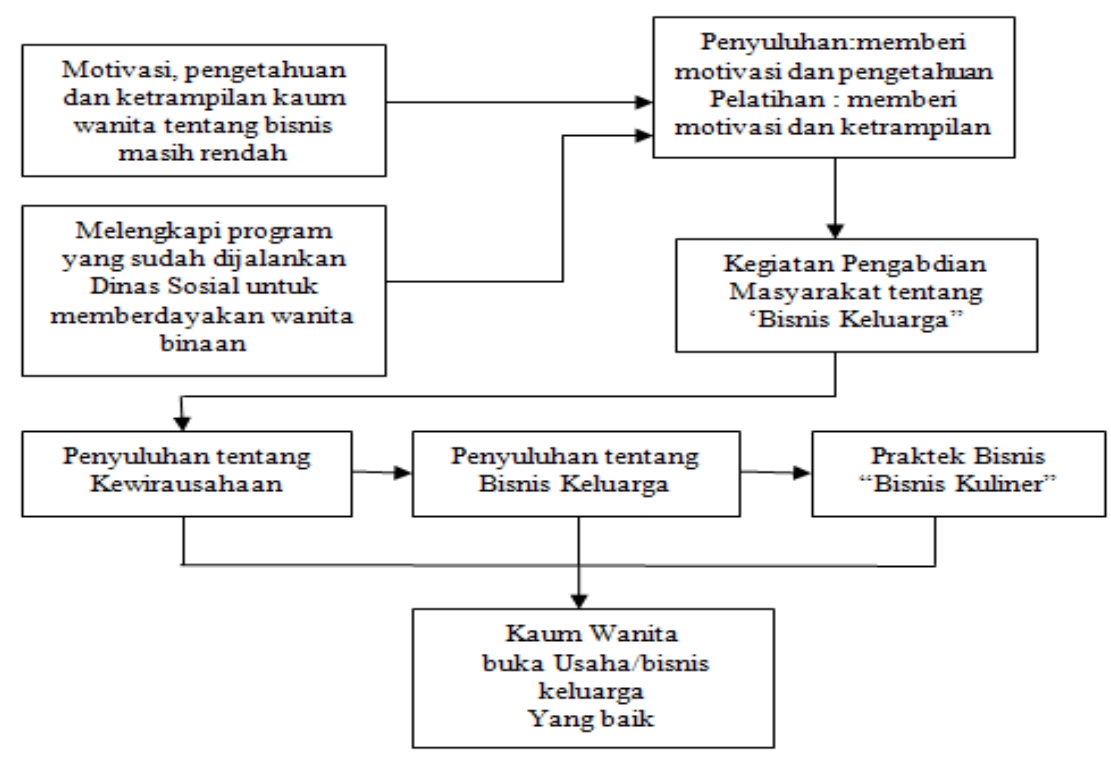

Gambar 1. Alur Pemecahan Masalah Kegiatan Pengabdian

\section{HASIL DAN PEMBAHASAN}

Kegiatan Pengabdian pada Masyarakat (PKM) yang dilaksanakan dengan acara tatap muka dan praktek tentang pemberdayaan kaum wanita tentang bisnis keluarga. Pertemuan tatap muka dengan metode ceramah (penyuluhan), praktek, dilanjutkan Tanya jawab dan diskusi. Kegiatan ini dilaksanakan pada hari Kamis tanggal 17 Juli 2018 dari pukul 19.00 sampai dengan selesai, sekitar jam 14.00

Peserta kegiatan berjumlah sekitar 50an orang yang terdiri dari wanita binaan Panti Sosial "Wanodyatama". Pelaksanan kegiatan PKM ini dilakukan oleh 3 (tiga) orang tim pengabdi dengan pokok bahasan yang disampaikan mengenai: 1) Pentingnya pemberdayaan kaum wanita, 2)Strategi pemberdayaan dengan bisnis keluarga, 3)Membangun bisnis keluarga dengan ketrampilan paraktis bidang kuliner.

Kegiatan yang diawali dengan :

1. memberikan ceramah atau penyuluhan oleh tim PKM, untuk membuka wawasan tentang bisnis untuk kesejahteraan keluarga.

2. Memberikan ceramah tentang kewirausahaan untuk memberikan motivasi dan gairah kerja kepada kaum wanita binaan

3. Melakukan diskusi ini, untuk menyelesaikan permasalahan, dan menghadapi tantangan ke depan.

4. kemudian dilanjutkan demonstrasi secara visual tentang pembuatan lunpia.

Berbagai pertanyaan diajukan secara antusias oleh para peserta dalam sesi tanya jawab. Secara garis besar inti dari pertanyaan para peserta antara lain meliputi hal hal :

1. Langkah langkah dalam membuka usaha,

2. Strategi yang jitu untuk membangun mengembangnkan bisnis keluarga.

Program pengabdian pada masyarakat berupa penyuluhan, pelatihan dan pendampingan bagi kaum wanita binaan Panti Sosial "Wanodyatama" secara garis besar dapat menambah pengetahuan, keterampilan dan lebih motivasi, percaya diri dalam menjalankan usahanya. 
Kegiatan ini memberikan pengaruh yang signifikan karena kaum wanita binaan lebih bersemangat dan termotivasi untuk mengembangkan usaha bisnis yang dapat meningkatkan kesejahteraan keluarga.

Hasil pelatihan ini akan bermanfaat bagi pengurus panti dengan wacana yang baru. Hasil kegiatan pengabdian ini secara garis besar mencakup beberapa komponen sebagai berikut:

1. Keberhasilan target jumlah peserta kegiatan,

2. Ketercapaian tujuan kegiatan,

3. Ketercapaian target materi yang telah direncanakan, dan

4. Kemampuan peserta dalam penguasaan materi

Target peserta pelatihan seperti direncanakan sebelumnya adalah paling tidak 25 anggota ternyata bias mencapai 50an. Sehingga pelaksanaan kegiatan ini dapat dikatakan bahwa target peserta tercapai $100 \%$. Angka tersebut menunjukkan bahwa kegiatan pengabdian dilihat dari jumlah peserta yang mengikuti dapat dikatakan berhasil/ sukses.

Pengembangan model kegiatan pada masyarakat ini adalah sebagai berikut :

1. Adanya pendampingan dari Dinas Sosial untuk memberikan pelatihan sebanyak mungkin supaya kaum wanita memiliki kompetyensi teknis untuk membuka usaha

2. Adanya pendampingan dari Pendidikan Tinggi untuk memberikan pelatihan soft skill dan membangun motivasi sehingga kaum wanita binaan mampu membuka dan mengembangkan usahanya.

Pengembangan model dengan system pendampingan ini dapat dilihat alurnya pada gambar 2 dibawah ini.

Hasil evaluasi dari kegiatan ini mencatat beberapa hal yang perlu diperhatikan yaitu :

1. Bentuk evaluasi yang dilakukan dengan pengamatan, pengawasan dan wawancara tentang materi yang diberikan dalam penyuluhan dan praktek. Dan memberikan hasil bahwa kaum wanita binaan sebagai peserta kegiatan merasa puas, senang dan termotivasi dalam membuka usaha (bisnis).

2. Kriteria evaluasi adalah menjadi kehadiran dan partisipasi peserta dalam kegiatan. Hasil menunjukan bahwa kehadiran peserta memuaskan karena 90\% dari jumlah populasi kaum wanita binaan di Panti Pelayanan Dinas Sosial Wanita "Wanodyatama" bersedia hadir. Pesrta juga memiliki keaktifan dalam bertanya jawab dengan nara sumber.

3. Sebagai tindak lanjut kegiatan ini adalah memberikan pelatihan bisnis dan pendampingan bagi kaum wanita binaan dalam pengembangan usaha/bisnis yang berbasis keluarga. 


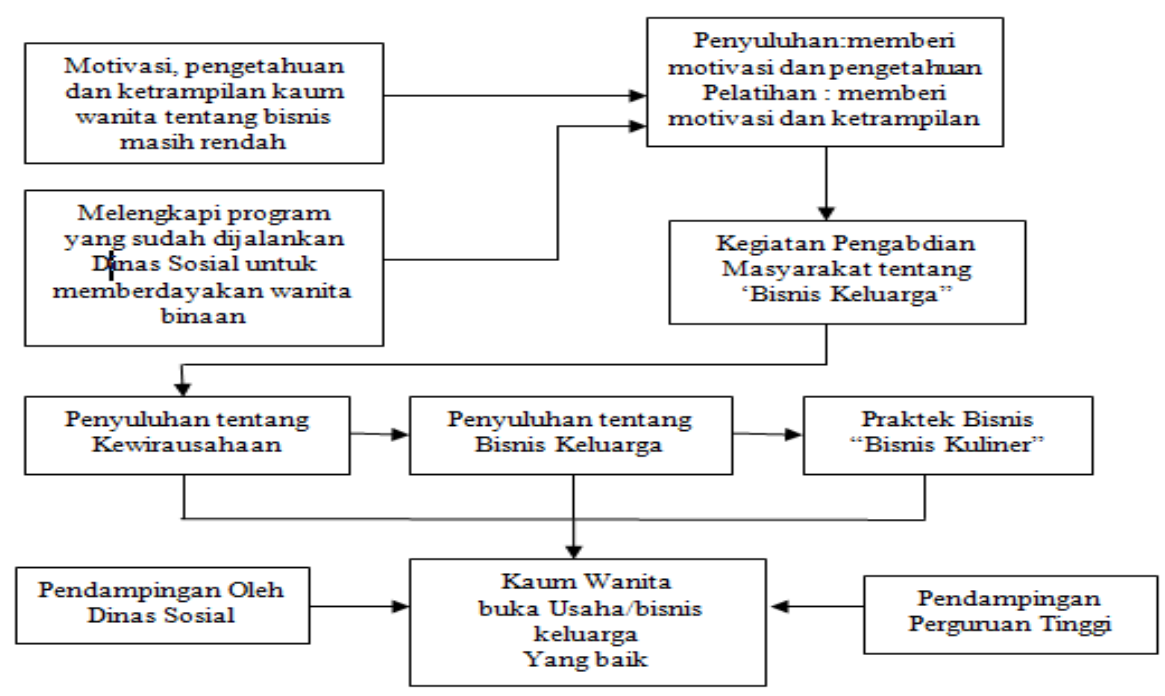

Gambar 2.Pengembangan model pengabdian pada masyarakat
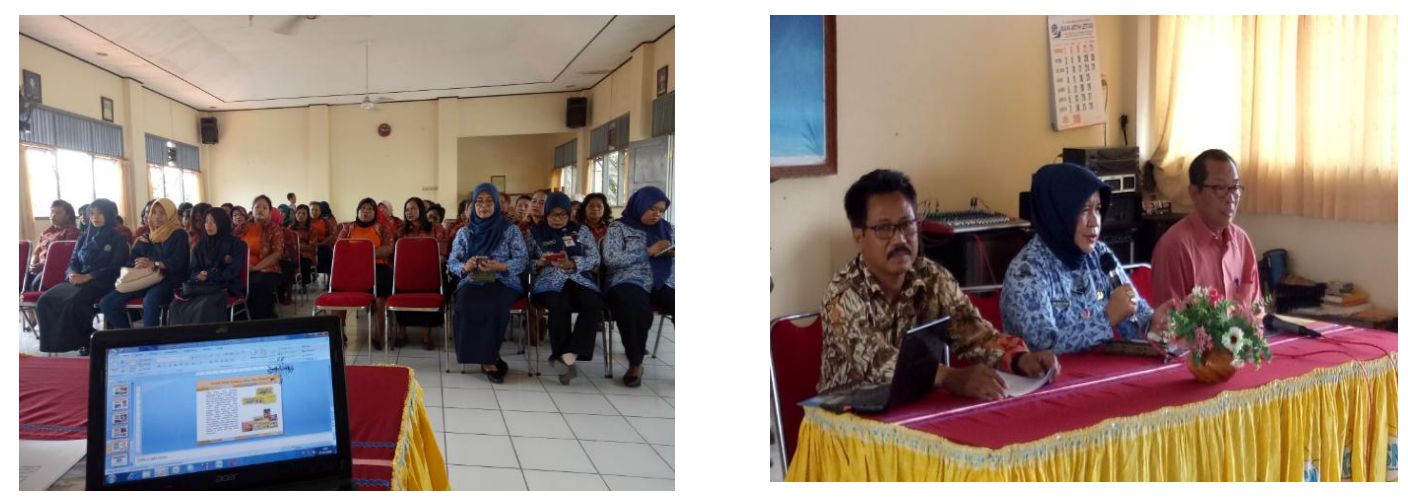

Gambar 3. Foto kegiatan pemberdayaan Kaum Wanita di Panti Sosial Wanodyatama Surakarta

\section{KESIMPULAN DAN SARAN}

1. Kesimpulan

Kesimpulan dari kegiatan pengabdian pada masyarakat ini adalah :

a. Secara kualitatif, yang dicapai dari kegiatan ini adalah : setiap kaum wanita binaan di Panti Pelayanan Dinas Sosial Wanita "Wanodyatama", dapat memiliki pengetahuan, pemahaman dan motivasi untuk membangun bisnis keluarga dan Pengembangan usaha kaum wanita dalam meningkatkan kesejahteraan dengan menjalankan bisnis keluarga.

b. Secara kuantitatif adalah akan menjadikan kaum wanita sebagai calon wirausahawan yang tangguh dan mandiri : adanya peningkatan kualitas dan kuantitas usaha yang berdampak kepada kesejahteraan anggota keluarga para wanita binaan, untuk memberikan nilai tambah terhadap peningkatan kualitas dan kuantitas sumber daya manusia khususnya kaum wanita, dan untuk mengangkat perekonomian daerah. 
2. Saran

Dalam kegiatan pengabdian berikutnya perlunya pendampingan secara tehnis pada para kaum wnita untuk diberi pelatihan menggunakan akan meningkatkan kesejahteraan keluarga dan berdampak pada perekonomian daerah.

\section{DAFTAR PUSTAKA}

Onny S. Prijono dan A.M.W. Pranarka. 1996. Pemberdayaaan Konsep Kebijakan dan Implementasi. Cetakan I. Jakarta: Penerbit Centre for Strategic and International Studies (CSIS).

Randy R. Wrihatnolo dan Riant Nugroho Dwidjowijoto. 2007. Manajemen Pemberdayaan. Cetakan 1. Jakarta: Penerbit PT. Elex Media Komputindo.

Roesmidi, H., dan Riza Risyanti. 2006. Pemberdayaan Masyarakat. Cetakan 2. Sumedang: Penerbit Al-qaprint Jatinangor.

Sunyoto Usman. 2006. Pembangunan dan Pemberdayaan Masyarakat. Cetakan IV. Yogyakarta: Penerbit Pustaka Pelajar. 